\title{
The effect of short-term nutritional supplementation of ewes with lupin grain (Lupinus luteus) on folliculogenesis, the concentrations of hormones and glucose in plasma and follicular fluid and the follicular levels of $\mathbf{P}_{450}$ aromatase and IRS-1, -2 and -4
}

\author{
A Somchit-Assavacheep ${ }^{1,3}$, B K Campbell ${ }^{4}$, M Khalid $^{2}$, N R Kendall ${ }^{5}$ and R J Scaramuzzi $i^{1,6}$ \\ Departments of ${ }^{1}$ Veterinary Basic Sciences and ${ }^{2}$ Veterinary Clinical Sciences, Royal Veterinary College, Hawkshead \\ Lane, North Mimms, Hertfordshire AL9 7TA, UK, ${ }^{3}$ Department of Animal Husbandry, Faculty of Veterinary Science, \\ Chulalongkorn University, Bangkok 10330, Thailand, ${ }^{4}$ Division of Obstetrics and Gynaecology, School of Human \\ Development, Queens Medical Centre, University of Nottingham, Nottingham NG7 2UH, UK, ${ }^{5}$ Sutton Bonnington \\ Campus, School of Veterinary Medicine and Science, University of Nottingham, Loughborough LE12 5RD, \\ UK and ${ }^{6}$ UMR Physiologie de la Reproduction et des Comportements, INRA, 37380 Nouzilly, France
}

Correspondence should be addressed to A Somchit-Assavacheep at Department of Animal Husbandry, Faculty of Veterinary Science, Chulalongkorn University, Bangkok 10330,Thailand; Email: anongnart.s@chula.ac.th

\begin{abstract}
An experiment was conducted on 48 ewes during follicular and luteal phases of the oestrous cycle to determine the effect of a 5-day lupin grain supplementation ( $500 \mathrm{~g} /$ day) on folliculogenesis, plasma concentrations of glucose, insulin, $\mathrm{FSH}$ and oestradiol-17 $\beta$ ( $\left.\mathrm{E}_{2}\right)$, follicular fluid concentrations of glucose, $E_{2}$, androstenedione and progesterone and the levels of $P_{450}$ aromatase and insulin receptor substrate 1 (IRS-1), -2 and -4 in theca and granulosa cells. Average weight did not differ between lupin-fed and control groups. The numbers of follicles were increased $\left(P<0.05 ; \chi^{2}\right)$ in the lupin-fed group. The plasma concentrations of glucose $(P<0.05 ;$ ANOVA) and insulin $\left(P<0.001\right.$; ANOVA) were higher in lupin-fed ewes. The plasma concentrations of FSH were not different but those of $E_{2}$ were decreased $(P<0.001)$ in the lupin-fed group. Both the follicular fluid concentration of $E_{2}(P<0.05)$ and the level of $P_{450}$ aromatase in granulosa cells $\left(P<0.05 ;\right.$ ANOVA) were decreased in the lupin-fed group, but only during the follicular phase. The level of $P_{450}$ aromatase in granulosa cells was positively correlated with the concentration of $E_{2}$ in follicular fluid $(r=0.820 ; P<0.001 ; A N O V A)$. The levels of IRS-1 and -2 in theca and granulosa cell lysates were increased in the lupin-fed group. These data suggest that insulin has a local role in the control of folliculogenesis and is likely to be a mediator of the effects of dietary energy intake on ovulation rate. We suggest that insulin acting through IRS proteins mediates the reproductive actions of insulin in the follicle and that IRS-1 and -2 are nutritionally regulated mediators of the action of insulin in the follicle.
\end{abstract}

Reproduction (2013) 145 319-333

\section{Introduction}

The effects of nutrition on reproduction are well known and widely reported, and of the environmental factors influencing ovulation rate nutrition is one of the most important (Downing \& Scaramuzzi 1991, Scaramuzzi et al. 2006). This effect of nutrition on ovulation rate in the ewe has major implications for the reproductive performance of sheep and this has been known for some time (Lindsay 1976). Over the years, a considerable body of research has identified three recognized and generally accepted effects of nutrition on ovulation rate; these are i) the static effect, ii) the dynamic effect and iii) the immediate or short-term effect. An example of the short-term effect of nutrition on ovulation rate is supplementation with lupin grain for 4-6 days before ovulation (Teleni et al. 1989). This treatment increases the number of small follicles (Haresign 1981), ovulation rate (Oldham \& Lindsay 1984) and prevents atresia of large follicles (Haresign 1981). Most of the investigations describing the effect of nutrition on litter size and more recently ovulation rate and folliculogenesis have been descriptive studies, and although these are detailed and well described, knowledge of their underlying physiological mechanisms is only now beginning to emerge. The current view is that nutrition modulates folliculogenesis through the actions of metabolic hormones such as insulin, insulin-like growth factor 1, GH and leptin. All 
these have demonstrated local effects on follicle development and are likely mediators of the effects of nutrition on ovulation rate (Scaramuzzi et al. 2011) acting to modulate the action of gonadotrophins, steroids and inhibin in follicles.

Insulin had specific effects on granulosa and theca cell function in the ewe (Campbell et al. 1996) and insulin and glucose acted together to influence directly ovarian function in situ (Downing et al. 1999). The insulindependent glucose transporter type 4 (GLUT4) was detected in granulosa and theca cells of ovine follicles implying that changes in insulin-mediated glucose uptake by the follicle modulated its function (Williams et al. 2001). Thus, it is apparent that insulin can affect folliculogenesis by regulating the cellular uptake of glucose suggesting a role for insulin in the mechanism of nutritional effects on folliculogenesis in sheep (Scaramuzzi et al. 2006).

The insulin receptor that is present in the ovary is a ligand-activated tyrosine kinase. On activation, the insulin receptor phosphorylates a variety of downstream kinases including the insulin receptor substrate (IRS) proteins. The IRS proteins direct and regulate the postreceptor insulin signalling pathways that control glucose uptake, glucose metabolism, protein synthesis, RNA and DNA synthesis and cell survival. Thus, the IRS proteins are potential mediators of dietary effects on folliculogenesis (Brüning et al. 2000, Burks et al. 2000, Yen et al. 2004) possibly by interacting with the gonadotrophin-stimulated CAMP/protein kinase A (PKA) signalling pathways that controls steroid secretion in the follicle. Because the IRSs can specify the action of insulin along diverse signal cascades, it is reasonable to suggest that altered patterns of IRSs expression reflect altered insulin signalling in the follicle. Studies based largely on knockout mice have demonstrated that altered patterns of some IRSs impaired ovarian function (Fantin et al. 2000). Thus, the patterns of IRS expressions in theca and granulosa cells in response to diet may be associated with alterations in the physiological function of follicles. The role of the IRSs has not been examined in follicles from ewes fed with a high-energy diet such as lupin grain. We suggest that diet-induced changes in the circulating concentrations of insulin regulate follicular steroidogenesis by modifying follicular responsiveness to gonadotrophin stimulation and that the cellular actions of gonadotrophins are subject to local regulation by insulin acting through the IRSs to mediate the effects of dietary energy intake on folliculogenesis.

The aim of this study was to investigate, in sheep during the follicular and luteal phases of the oestrous cycle, the effects of feeding a high-energy diet on folliculogenesis and on the plasma and follicular fluid concentrations of glucose, insulin, FSH and oestradiol $\left(E_{2}\right)$ and the levels of $P_{450 a r o m}$ and IRS-1, -2 and -4 in theca and granulosa cells.

\section{Results}

Three ewes from the lupin-fed groups (one follicular phase and two luteal phases) refused to eat the lupin grain supplement and these three ewes have been excluded from the data set.

\section{Ewe body weight}

The average weights (mean \pm s.E.M.) in the lupin-fed groups for both the follicular and the luteal phases $(n=21)$ at sponge removal, at the start of lupin feeding and at cull were $45.5 \pm 1.18,44.2 \pm 1.17$ and $43.6 \pm 1.04 \mathrm{~kg}$ respectively, and similarly, for the control groups for both the follicular and the luteal phases $(n=24)$, they were 45.5 $\pm 1.13,44.1 \pm 0.93$ and $43.6 \pm 0.88 \mathrm{~kg}$. There were no significant differences within or between groups.

\section{Ovarian morphology}

There was at least one corpus luteum (CL) in each ewe. The CLs of ewes in the luteal phase were red or dark pink in colour, with diameters of 7-11 mm. The nonfunctional CLs of ewes in the follicular phase were pale pink in colour, with diameters of $4-8 \mathrm{~mm}$. The numbers of follicles dissected from the ovaries of lupin-fed and control ewes in the luteal and follicular phases are shown in Table 1. The average number of follicles per ewe in the lupin-fed and control groups were significantly different $(P=0.021)$. However, there were no effects of stage of oestrous cycle $(P=0.945)$, and the interaction was not significant $(P=0.608)$.

\section{Plasma glucose and plasma hormone concentration}

\section{Glucose}

The plasma glucose concentrations are illustrated in Fig. 1. At the start of lupin feeding (day 0), the glucose concentrations (mean \pm s.E.M.) in lupin-fed $(n=21)$ and control groups $(n=24)$ were $55.9 \pm 1.26$ and 56.9 $\pm 1.09 \mathrm{mg} / \mathrm{dl}$ respectively. There was a significant effect of time $(P<0.001)$ and a significant interaction between time and supplementation $(P<0.001)$. Exploration of this interaction showed that the plasma glucose concentrations in lupin-fed and control groups were significantly different $(P<0.05)$ from day 3 to the end of the lupin-feeding period. Following the end of lupin feeding, the plasma concentrations of glucose were not different $(P=0.138)$.

\section{Insulin}

The plasma insulin concentrations are illustrated in Fig. 1. At the start of lupin feeding (day 0), the insulin concentrations (mean \pm S.E.M.) in lupin-fed and control groups were $0.35 \pm 0.05$ and $0.35 \pm 0.03 \mathrm{ng} / \mathrm{ml}$ respectively. By day 2 after the start of lupin feeding, the concentration of plasma insulin increased 
Table 1 The mean \pm S.E.M. number of corpora lutea and follicles per ewe classified by diameter $(\mathrm{mm})$ in lupin-fed and control groups at two stages of the oestrous cycle (luteal and follicular).

\begin{tabular}{|c|c|c|c|c|c|c|c|}
\hline \multirow[b]{2}{*}{ Treatment } & \multirow[b]{2}{*}{ Stage } & \multirow[b]{2}{*}{ Corpora lutea } & \multicolumn{4}{|c|}{ Follicle classes } & \multirow{2}{*}{$\begin{array}{c}\text { Total follicles } \\
\text { per ewe }\end{array}$} \\
\hline & & & $>3.5 \mathrm{~mm}$ & $2.5-\leq 3.5 \mathrm{~mm}$ & $2.0-<2.5 \mathrm{~mm}$ & $<2.0 \mathrm{~mm}$ & \\
\hline \multirow[t]{2}{*}{ Lupin } & Luteal $(n=9)$ & $1.78 \pm 0.22^{\mathrm{a}}$ & $2.00 \pm 0.24^{\mathrm{a}}$ & $7.22 \pm 0.70^{\mathrm{a}}$ & $11.89 \pm 1.99^{\mathrm{a}}$ & $10.56 \pm 1.29^{a, b}$ & $31.67 \pm 3.10^{\mathrm{a}}$ \\
\hline & Follicular $(n=8)$ & $1.63 \pm 0.18^{\mathrm{a}}$ & $2.25 \pm 0.49^{\mathrm{a}}$ & $3.38 \pm 0.71^{\mathrm{b}, \mathrm{c}}$ & $10.88 \pm 1.38^{\mathrm{a}, \mathrm{b}}$ & $14.75 \pm 4.02^{\mathrm{a}}$ & $31.25 \pm 4.39^{\mathrm{a}, \mathrm{d}}$ \\
\hline \multirow[t]{2}{*}{ Control } & Luteal $(n=9)$ & $1.44 \pm 0.18^{\mathrm{a}}$ & $1.67 \pm 0.29^{\mathrm{a}}$ & $4.22 \pm 0.76^{b}$ & $7.89 \pm 1.84^{b}$ & $8.44 \pm 0.77^{b}$ & $22.22 \pm 2.77^{\mathrm{b}, \mathrm{c}}$ \\
\hline & Follicular $(n=9)$ & $1.56 \pm 0.18^{\mathrm{a}}$ & $1.89 \pm 0.20^{\mathrm{a}}$ & $2.56 \pm 0.44^{\mathrm{C}}$ & $10.78 \pm 1.23^{\mathrm{a}}$ & $8.89 \pm 1.90^{\mathrm{b}}$ & $24.11 \pm 2.81^{b, d}$ \\
\hline
\end{tabular}

Within columns, number with different superscripts differ significantly $(P<0.05)$

significantly in the lupin-fed group and remained higher than that in the controls for the duration of lupin feeding $(P<0.001)$. There was a significant effect of time $(P<0.001)$ and the time by supplementation interaction was significant $(P<0.001)$.

\section{FSH}

The plasma FSH concentrations are illustrated in Fig. 2. At the start of lupin feeding (day 0), the plasma FSH concentrations (mean \pm S.E.M.) in lupin-fed and control groups were $1.60 \pm 0.12$ and $1.68 \pm 0.11 \mathrm{ng} / \mathrm{ml}$ respectively. After the start of lupin feeding, the concentration of plasma FSH was not different between groups $(P=0.388)$ and the interaction between supplementation and time was not significant $(P=0.211)$.

\section{Oestradiol-17\%}

The plasma concentrations of $E_{2}$ are illustrated in Fig. 2. At the start of lupin feeding (day 0 ), the concentrations of $E_{2}$ (mean \pm s.E.M.) in lupin-fed and control groups were
$6.13 \pm 0.61$ and $6.42 \pm 0.52 \mathrm{pg} / \mathrm{ml}$ respectively. After the start of lupin feeding, the concentration of plasma $E_{2}$ decreased significantly in the lupin-fed group and remained lower than the controls $(P=0.001)$. There was a significant effect of time $(P<0.001)$ and the time by supplementation interaction was significant $(P=0.001)$. During follicular phase, after the induction of luteolysis with $\mathrm{PGF}_{2 \alpha}$, plasma concentrations of $\mathrm{E}_{2}$ in the lupin-fed $(n=11)$ and control groups $(n=12)$ were significantly increased at 14 and $20 \mathrm{~h}$.

\section{Progesterone}

The progesterone profiles confirmed that all ewes were undergoing normal oestrous cycles (data not shown).

\section{Follicular fluid glucose and hormone concentrations}

Glucose

Follicle diameter. There was a significant effect of follicle size $(P=0.010)$ but not of supplementation $(P=0.054)$ or

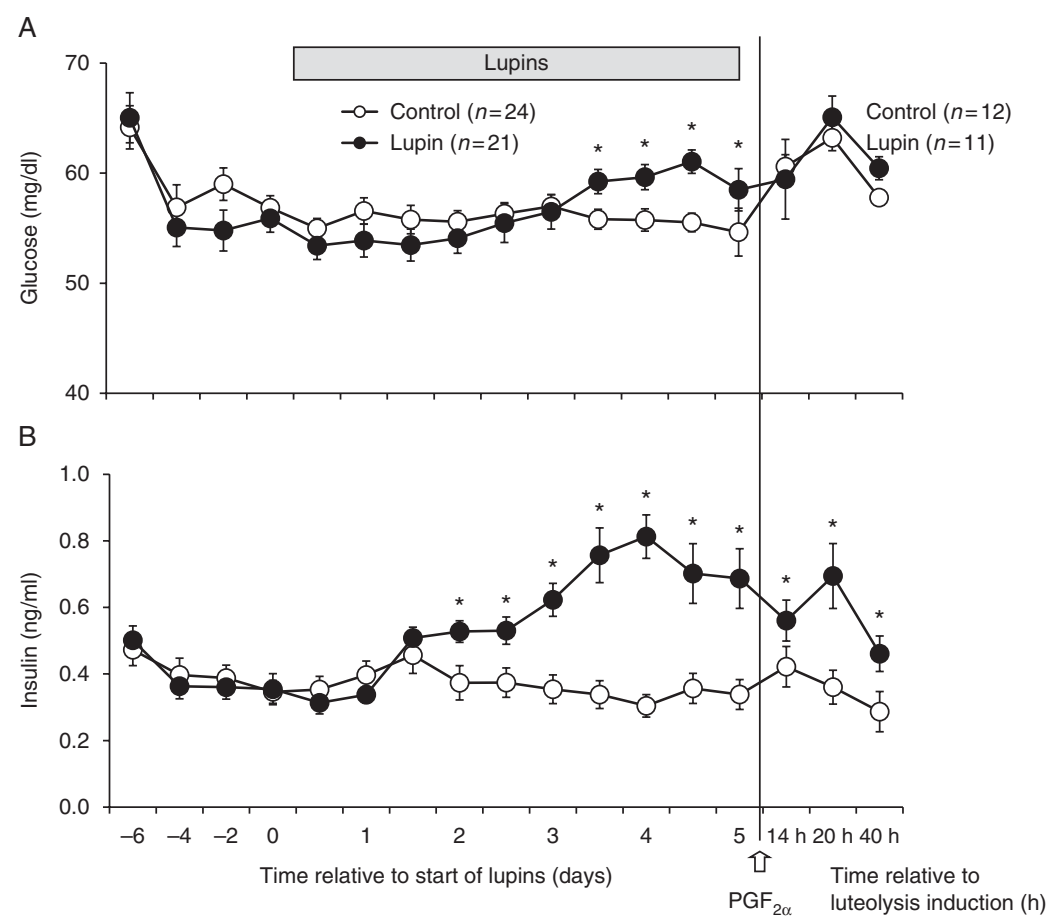

Figure 1 The mean ( \pm S.E.M.) concentrations of glucose (A) and insulin (B) in jugular venous blood in control $(n=24)$ and lupin-fed $(n=21)$ ewes. Blood samples were taken every second day at $0900 \mathrm{~h}$ for 8 days and then from the start of the lupin-feeding period, twice daily at $0900 \mathrm{~h}$ (before feeding) and $1400 \mathrm{~h}$, then blood samples were taken at 14, 20 and $40 \mathrm{~h}$ after $\mathrm{PGF}_{2 \alpha}$ injection. Luteolysis was induced in the controlfollicular phase $(n=12)$ and lupin-follicular phase $(n=11)$ groups with an injection of $\mathrm{PGF}_{2 \alpha}$ on day 5 of lupin-feeding period. An asterisk indicates a significant difference $(P<0.05)$ between groups. 

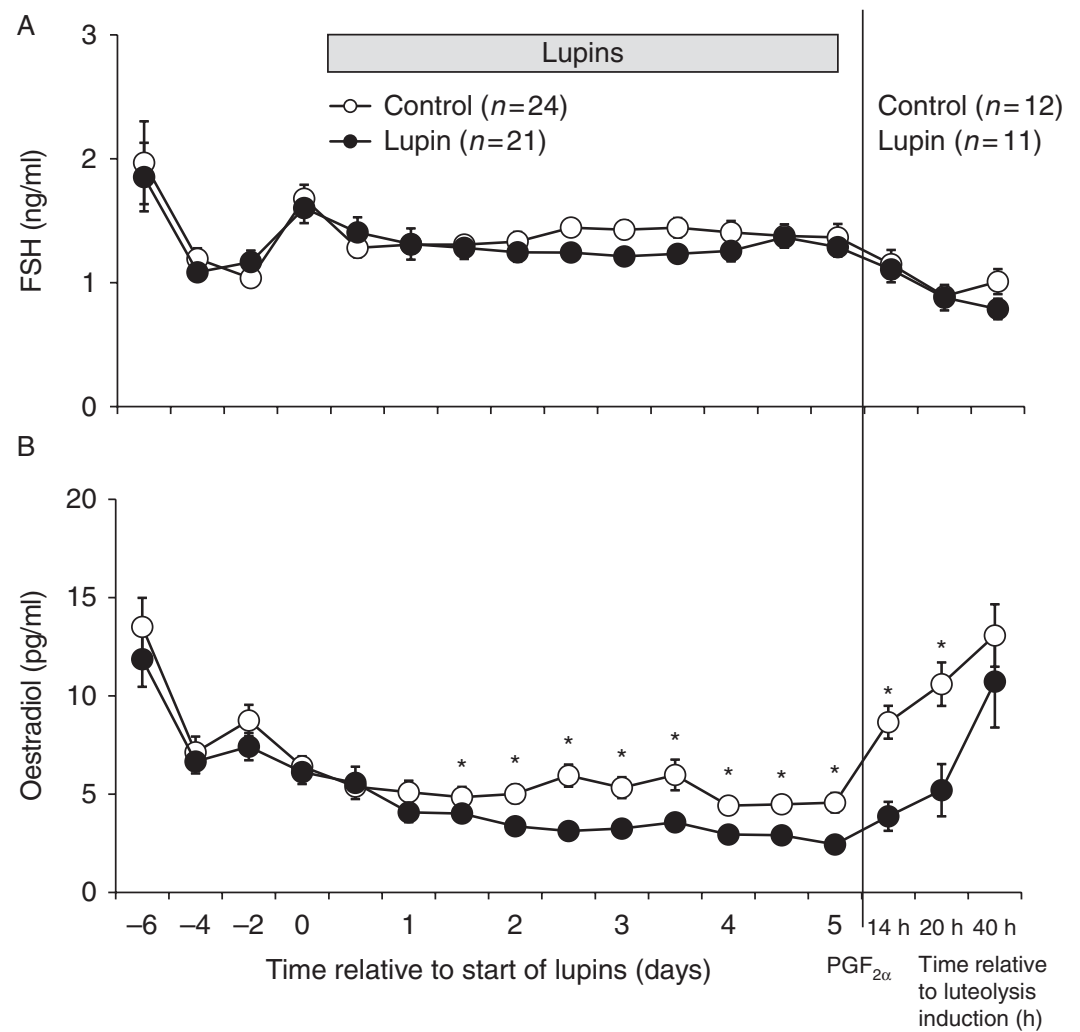

Figure 2 The mean ( \pm S.E.M.) concentrations of FSH (A) and oestradiol-17 $\beta$ (B) in jugular venous blood in control $(n=24)$ and lupin-fed groups $(n=21)$. Blood samples were taken every second day at $0900 \mathrm{~h}$ over a period of 8 days, then from the start of lupin feeding, blood samples were taken twice daily at $0900 \mathrm{~h}$ (before feeding) and $1400 \mathrm{~h}$, then blood samples were taken at 14, 20 and $40 \mathrm{~h}$ after $\mathrm{PGF}_{2 \alpha}$ injection. Luteolysis was induced in the control-follicular phase $(n=12)$ and lupin-follicular phase $(n=11)$ groups with an injection of $\mathrm{PGF}_{2 \alpha}$ on day 5 of lupin-feeding period. An asterisk indicates a significant difference $(P<0.05)$ between groups.

phase of the oestrous cycle ( $P=0.885)$ on the concentration of glucose in follicular fluid (Fig. 3).

Oestrogenicity. There were no effects of oestrogenicity $(P=0.460)$, supplementation $(P=0.302)$ or phase of the oestrous cycle $(P=0.485)$ on the follicular fluid concentration of glucose but the supplementation by phase of the oestrous cycle interaction was significant $(P=0.038)$. Exploration of this interaction showed that the mean follicular fluid concentration of glucose in oestrogenic and non-oestrogenic follicles in luteal phase was decreased in the lupin-fed groups ( $P<0.05$; Fig. 4$)$.

\section{Oestradiol-17 $\beta$}

Follicle diameter. There were significant effects of follicle size $(P<0.001)$, phase of the oestrous cycle $(P<0.001)$ and supplementation $(P=0.016)$ on the follicular fluid concentration of $E_{2}$ (Fig. 3). There were significant interactions between supplementation and follicle size $(P=0.018)$, phase of the oestrous cycle and follicle size $(P<0.001)$ but not between supplementation and phase of the oestrous cycle $(P=0.956)$. The concentration of $\mathrm{E}_{2}$ in follicular fluid was significantly increased $(P<0.05)$ in large follicles ( $\geq 3.5 \mathrm{~mm}$ in diameter; Fig. 3$)$ in all groups. Lupin feeding had effects in follicles $\geq 3.5 \mathrm{~mm}$ in diameter where it decreased follicular fluid $E_{2}$ in the lupin-fed groups in both luteal phase $(P<0.05)$ and follicular phase $(P<0.05)$.

Oestrogenicity. There were significant effects of oestrogenicity $(P<0.001)$ and phase of the oestrous cycle
( $P=0.007)$ but not of supplementation $(P=0.188)$ on the follicular fluid concentration of $E_{2}$ and the oestrogenicity by phase of the oestrous cycle interaction was significant $(P=0.008)$; exploration of this interaction shows that lupins decreased follicular fluid $E_{2}$ in the lupin-fed groups in follicular phase $(P<0.05)$ but not in the luteal phase (Fig. 4).

\section{Androstenedione}

Follicle diameter. The follicular fluid concentrations of androstenedione are shown in Fig. 3. There were significant effects of follicle size $(P=0.017)$ and phase of the oestrous cycle $(P=0.031)$ but not of supplementation $(P=0.122)$ but the supplementation by phase of the oestrous cycle interaction was significant $(P=0.007)$. Thus, in the luteal but not in the follicular phase, the concentration of androstenedione in follicular fluid was decreased $(P<0.05)$ in the lupin-fed group when compared with controls.

Oestrogenicity. There were significant effects of oestrogenicity $(P=0.025)$ and phase of the oestrous cycle $(P=0.026)$ but not of supplementation $(P=0.138)$ on the follicular fluid concentration of androstenedione and the supplementation by phase of the oestrous cycle interaction was significant $(P<0.001)$. The follicular fluid concentration of androstenedione in luteal phase was decreased in the lupin-fed group for both oestrogenic $(P<0.05)$ and non-oestrogenic $(P<0.05)$ follicles (Fig. 4). 


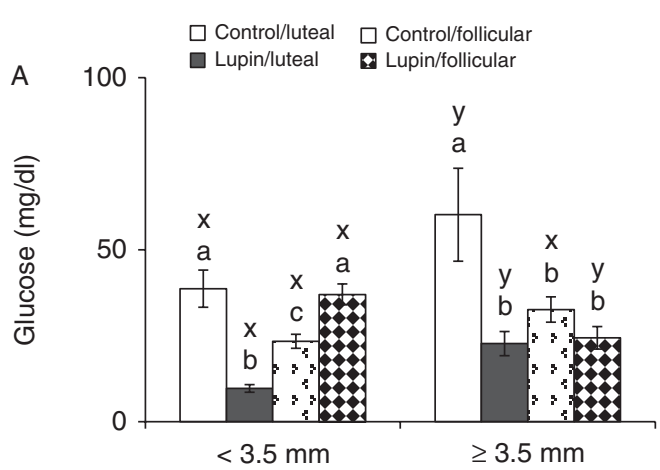

Follicle diameter

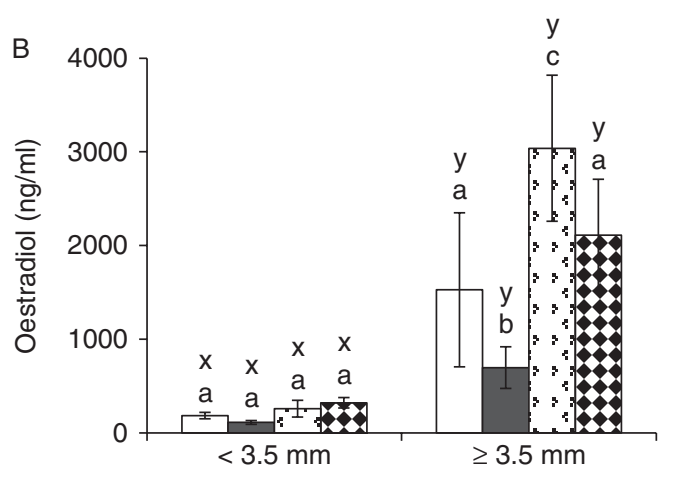

Follicle diameter

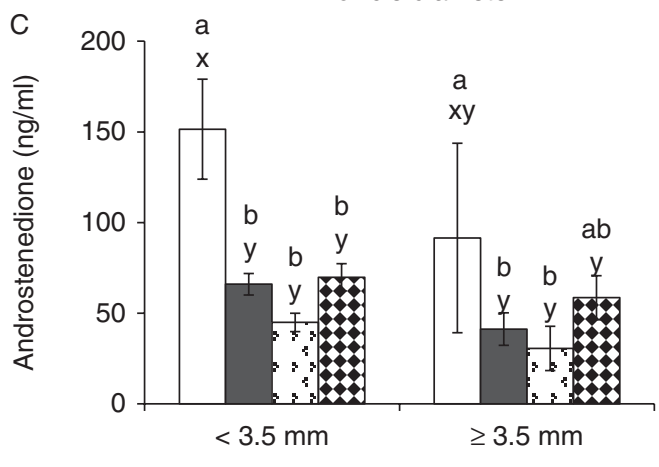

Follicle diameter

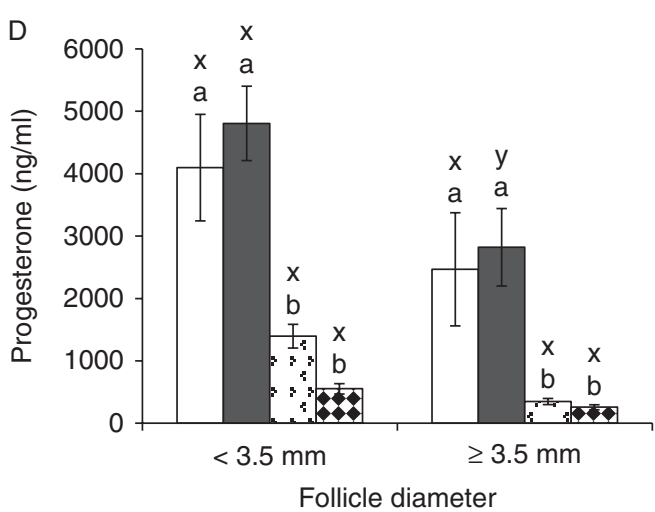

Figure 3 The mean ( \pm s.E.M.) concentrations of glucose (A), oestradiol (B), androstenedione (C) and progesterone (D) in follicular fluid from follicles $<3.5$ and $\geq 3.5 \mathrm{~mm}$ in diameter from four groups of Welsh Mountain ewes. The letters a, b and c compare differences within follicle size and the letters $\mathrm{x}$ and $\mathrm{y}$ compare differences between follicle sizes. Different letters indicate a significant difference $(P<0.05)$

\section{Progesterone}

Follicle diameter. The concentrations of progesterone in follicular fluid are shown in Fig. 3. There were significant effects of follicle size $(P=0.026)$ and phase of the oestrous cycle $(P<0.001)$ but not of supplementation $(P=0.750)$. The concentrations of progesterone in follicular fluid were significantly decreased $(P<0.05)$ in the follicular phase. The follicular fluid progesterone concentrations in the lupin-fed ewes during the luteal phase were significantly decreased $(P<0.05)$ in follicles $\geq 3.5 \mathrm{~mm}$ compared with those $<3.5 \mathrm{~mm}$ in diameter.

Oestrogenicity. There was a significant effect of phase of the oestrous cycle $(P<0.001)$ but not of oestrogenicity $(P=0.586)$ or supplementation $(P=0.497)$ on the follicular fluid concentration of progesterone. The concentration of progesterone was decreased $(P<0.05)$ in the control-follicular and lupin-follicular groups from both non-oestrogenic and oestrogenic follicles (Fig. 4).

\section{The levels of $\boldsymbol{P}_{450 a r o m}$ in theca and granulosa cells}

\section{Follicle diameter}

There was no detectable $\mathrm{P}_{450 a r o m}$ in the theca cell lysates in any of the samples. For granulosa cells (Table 2), levels of aromatase were not significantly different in small and medium follicles. There was a significant effect of follicle size $(P<0.001)$ and the level of aromatase was significantly increased $(P<0.05)$ in large follicles compared with medium and small follicles. For large follicles, the level of aromatase was decreased in lupinfed ewes but the decrease was significant only in the follicular phase $(P<0.05)$.

\section{Oestrogenicity}

There was a significant effect of oestrogenicity $(P<0.001)$ but not of supplementation $(P=0.546)$ or of phase of the oestrous cycle $(P=0.986)$ on the levels of aromatase in granulosa cells. The supplementation by oestrogenicity interaction was significant $(P=0.038)$. The level of aromatase was significantly increased $(P<0.05)$ in oestrogenic follicles when compared with non-oestrogenic follicles in all groups. The level of $\mathrm{P}_{450 \text { arom }}$ was decreased $(P<0.05)$ in oestrogenic follicles during follicular phase in the lupin-fed group compared with the control group (Table 3).

\section{Correlation between $P_{450 a r o m}$ and follicular fluid $E_{2}$}

The level of aromatase in granulosa cell lysates was positively correlated with the concentration of $E_{2}$ in follicular fluid from the same follicle $(r=0.820$; $P<0.001$; Fig. 5). 

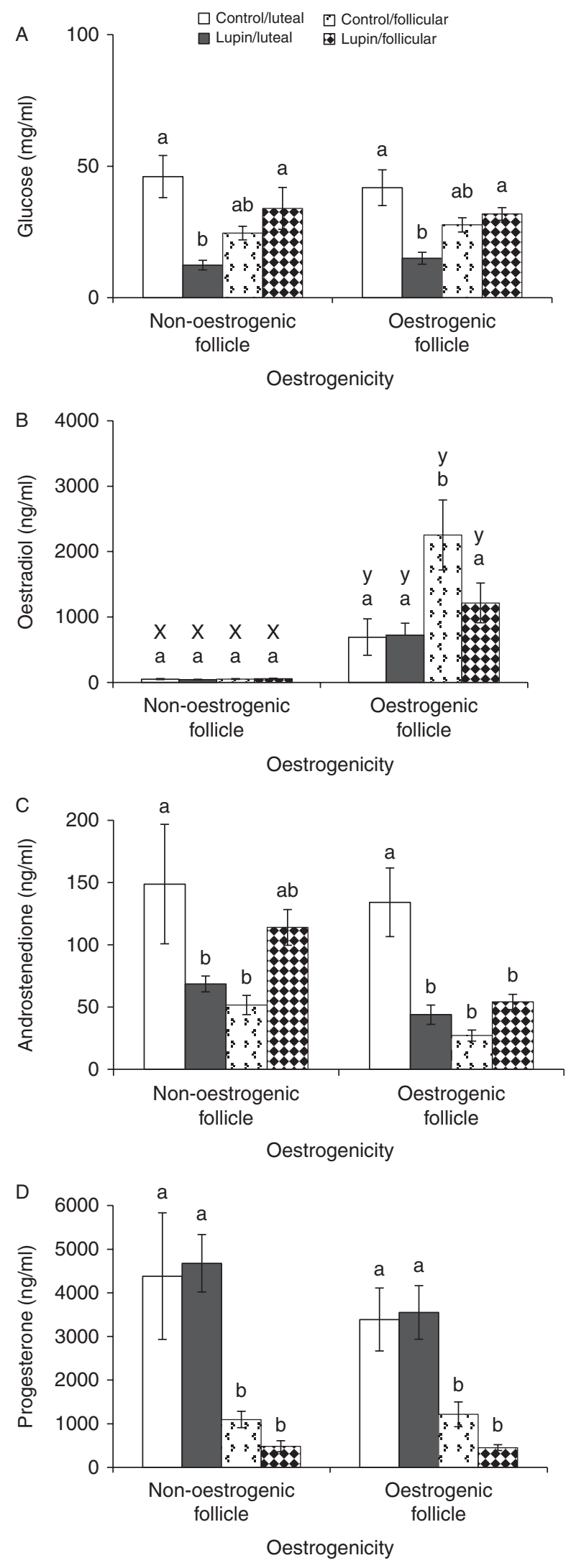

\section{Insulin receptor substrate 1}

\section{Follicle diameter}

IRS-1 was detectable in theca and granulosa cells from all follicle classes. In theca cells, the level of IRS-1 from large follicles was increased $(P<0.05)$ in the lupinfollicular group compared with control-follicular group. In granulosa cells, there was a significant effect of follicle size $(P=0.001)$, and the level of IRS-1 in granulosa cells from the lupin-follicular group was increased $(P<0.05)$ in large follicles (Table 2).

\section{Oestrogenicity}

The level of IRS- 1 in theca cells from oestrogenic follicles was increased $(P<0.05)$ in the lupin-follicular group when compared with control-follicular group. There was a significant effect of oestrogenicity $(P=0.006)$ on the level of IRS- 1 in granulosa cells. The levels of IRS- 1 in theca and granulosa cells from the lupin-luteal and lupin-follicular groups were significantly increased $(P<0.05)$ in oestrogenic follicles (Table 3$)$.

\section{Insulin receptor substrate 2}

\section{Follicle diameter}

In theca cells, there was a significant effect of supplementation $(P=0.004)$ and the interaction between the phase of the oestrous cycle and follicle size was significant $(P=0.005)$. The levels of IRS- 2 in theca cells were increased $(P<0.05)$ in the lupin-fed group during follicular phase compared with the control group (Table 2). The levels of IRS-2 in granulosa cells from all follicle classes were increased $(P<0.05)$ in the lupin-fed groups compared with the control groups.

\section{Oestrogenicity}

The level of IRS-2 in theca and granulosa cells from oestrogenic follicles was increased $(P<0.05)$ in the lupin-fed groups during both the luteal and the follicular phases (Table 3).

\section{Insulin receptor substrate 4}

Follicle diameter

In theca cells, there was a significant supplementation by phase of the oestrous cycle interaction $(P=0.010)$ on the level of IRS-4. The level of IRS-4 in theca cells was decreased $(P<0.05)$ in the lupin-fed group

$\overline{\text { Figure } 4 \text { The mean ( } \pm \text { s.E.M.) concentrations of glucose (A), oestradiol (B), }}$ androstenedione $(\mathrm{C})$ and progesterone $(\mathrm{D})$ in follicular fluid from non-oestrogenic $(<100 \mathrm{ng} / \mathrm{ml})$ and oestrogenic $(\geq 100 \mathrm{ng} / \mathrm{ml})$ follicles from four groups of Welsh Mountain ewes. The letters a and b compare differences within oestrogenicity class and the letters $x$ and $y$ compare differences between oestrogenicity class. Different letters indicate a significant difference $(P<0.05)$. 


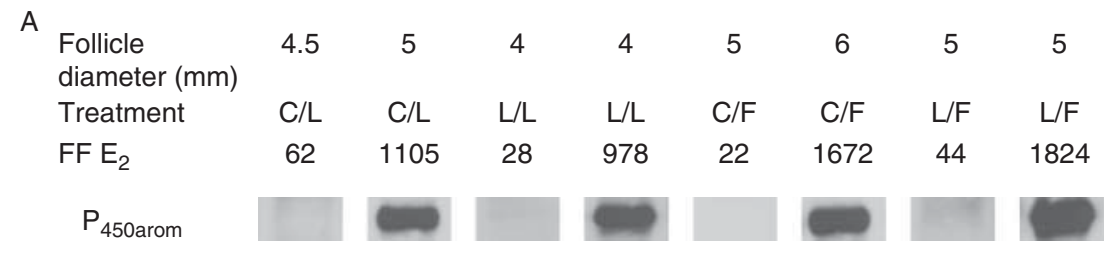

B

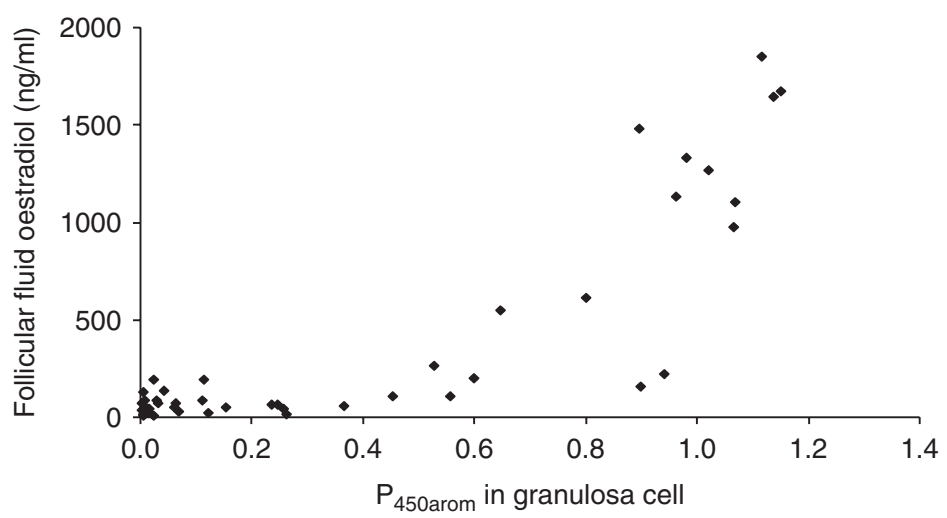

Figure 5 Positive correlation between the level of $\mathrm{P}_{450 \text { arom }}$ in granulosa cell lysates and the concentration of oestradiol- $17 \beta$ in follicular fluid from the same follicle (A: C/L, control-luteal; L/L, lupinluteal; $\mathrm{C} / \mathrm{F}$, control-follicular; L/F, lupin-follicular group; $F F E_{2}$, the concentration of ooestradiol-17 $\beta$ in follicular fluid $(\mathrm{ng} / \mathrm{ml})$ ). The individual $\mathrm{P}_{450 \text { arom }}$ levels in granulosa cells and the concentration of oestradiol- $17 \beta$ in follicular fluid from the same follicle (B).

during follicular phase compared with the control group for all follicle classes, but in large follicles it was increased $(P<0.05)$ in the lupin-fed group during luteal phase compared with the control group. The levels of IRS-4 in granulosa cells were increased in the lupin-fed group during the luteal phase (medium follicles) and the follicular phase (large follicles) compared with control follicles (both $P<0.05$ ) (Table 2).

\section{Oestrogenicity}

In theca cells, there was a significant supplementation by phase of the oestrous cycle interaction $(P=0.006)$ on the level of IRS-4. Lupins decreased $(P<0.05)$ the level of IRS-4 in theca cells during follicular phase for both oestrogenic and non-oestrogenic follicles. In granulosa cells there was a significant effect of phase of the oestrous cycle $(P=0.039)$ but not of oestrogenicity $(P=0.092)$ or supplementation $(P=0.096)$ on the level of IRS-4. In non-oestrogenic follicles the level of IRS-4 in granulosa cells from the follicular phase was increased $(P<0.05)$ in the lupin-fed group compared with control. The level of IRS-4 in granulosa cells from the lupin-luteal group was increased $(P<0.05)$ in oestrogenic compared with non-oestrogenic follicles (Table 3).

\section{Discussion}

The results of this study confirm that short-term dietary supplementation with lupin grain increased the number of follicles in ewes (Table 1). These data agree with several other studies (Downing \& Scaramuzzi 1991, Williams et al. 2001, Muñoz-Gutiérrez et al. 2002,
Viñoles et al. 2005, Letelier et al. 2009) showing that short-term nutritional supplementation of ewes increased the number of follicles. This short-term effect was independent of body weight again confirming the findings of several similar studies (Oldham \& Lindsay 1984, Nottle et al. 1985, King et al. 1991, Pearse et al. 1994, Somchit et al. 2007). These results suggest that rapid follicular responses to nutrition are associated with specific metabolic or nutritional signals rather than with body weight or body condition per se (Downing \& Scaramuzzi 1991).

It is clear that short-term feeding of lupin grain increased plasma concentrations of both glucose and insulin. The administration of glucose (Downing et al. 1995a, Rubio et al. 1997), feeding high-energy diets (Downing et al. 1995b) or infusing gluconeogenic amino acids (Downing et al. 1995c) to ewes increased circulating plasma insulin concentrations and they also increased follicle number and/or ovulation rate. Many papers have reported that short-term nutritional supplementation increased the plasma concentrations of insulin in ewes (Downing \& Scaramuzzi 1991, Downing et al. 1995b, Williams et al. 2001, Viñoles et al. 2005, Somchit et al. 2007), cows (Gutiérrez et al. 1997, Landau et al. 2000, Gong et al. 2002) and gilts (Ferguson et al. 2003). All these data suggest that the concentration of plasma insulin is key variable associated with the nutritional modulation of ovulatory responses. We suggest that increased plasma insulin leads to an increase in insulin-mediated glucose uptake by the ovary during the late luteal phase of the oestrous cycle that stimulates the growth of small follicles and/or prevents atresia in medium to large follicles, thereby increasing the pool of ovulatory follicles. 


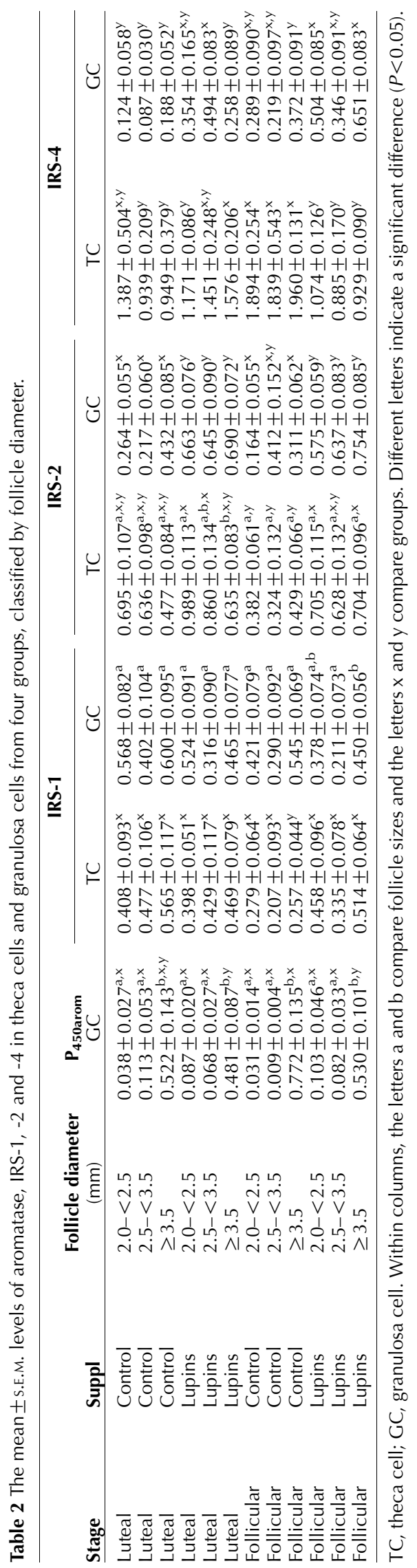

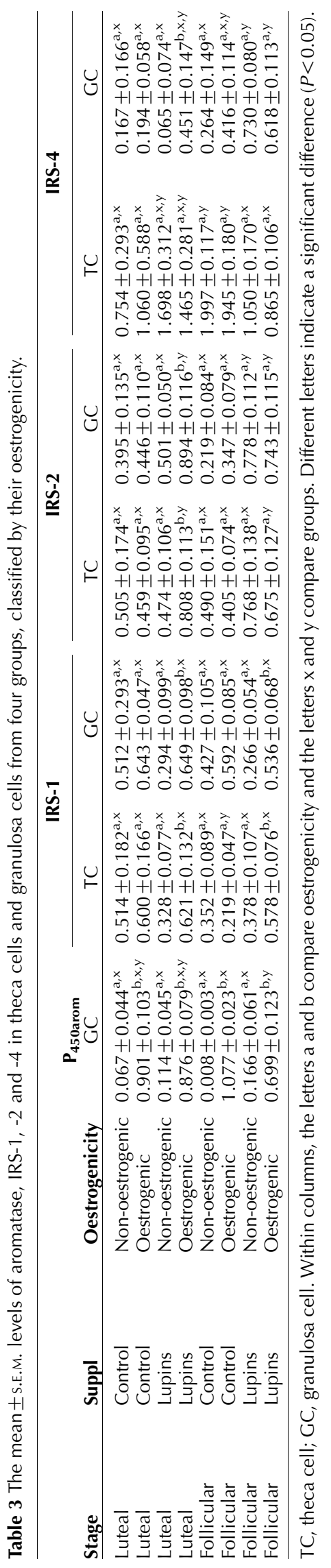

www.reproduction-online.org 
We have shown that the plasma concentrations of $E_{2}$ during the period of lupin feeding and in the subsequent early follicular phase of the oestrous cycle were decreased in the lupin-fed group; this result agrees with other studies that reported decreased concentrations of plasma $E_{2}$ in supplemented ewes (Adams et al. 1994, Letelier et al. 2008a, 2008b) and gilts (Ferguson et al. 2003). At the same time, the concentrations of FSH were not elevated by these treatments and this leads us to suggest that short-term nutritional supplementation may be acting locally in the follicle to perturb the negative feedback control systems that regulate folliculogenesis. It is not clear why the decreased secretion of $E_{2}$ did not result in a compensatory increase in $\mathrm{FSH}$, perhaps this was inhibited by an increased inhibin secretion from the increased number of small- and medium-sized follicles, known sources of inhibin (Campbell et al. 1990) as has been suggested (Scaramuzzi et al. 2011). This hypothesis remains to be tested. The concentrations of $E_{2}$ in follicular fluid reported in this study show unsurprisingly that it was higher in follicles $\geq 3.5 \mathrm{~mm}$ than in follicles $<3.5 \mathrm{~mm}$ (Chang et al. 1976, Carson et al. 1981, Henderson \& Franchimont 1981, Evans \& Martin 2000). We have also shown that the short-term feeding of lupin grain decreased follicular fluid $E_{2}$ in large follicles during both the luteal and the follicular phases; other studies have reported similar results (Peluso et al. 1991, Muñoz-Gutiérrez et al. 2005) and they are consistent with our other observations from this study, that is decreased concentration of plasma $E_{2}$ and decreased levels of granulosa cell aromatase in follicles from ewes supplemented with lupin grain.

In a previous investigation (Somchit et al. 2007), we reported that nutritional supplementation of ewes with lupin grain increased the follicular fluid concentrations of glucose during the luteal phase of the oestrous cycle. We were unable to confirm this finding in this study and in fact we found the opposite effect, that is, glucose concentrations in follicular fluid were reduced in the luteal phase of the oestrous cycle in ewes fed lupin grain.
The reasons for this discrepancy are not apparent, but in both studies, there were wide variations in the concentration of glucose in follicular fluid both among animals and among follicles within animals and perhaps our contradictory observations are a reflection of the inherent variability of glucose concentrations in follicular fluid.

The concentrations of androstenedione in follicular fluid were decreased in the lupin-fed ewes during the luteal phase and this decrease was associated with a reduction in follicular fluid $\mathrm{E}_{2}$. In addition, we found that androstenedione in follicular fluid tended to be higher in small follicles $<3.5 \mathrm{~mm}$ compared with follicles $\geq 3.5 \mathrm{~mm}$ in diameter. Androstenedione is increased in small follicles (Chang et al. 1976, Wise 1987), probably because it is a substrate for $E_{2}$ synthesis, and in large follicles, there is a high rate of utilization for $E_{2}$ synthesis.

The results of western immunoblotting from granulosa and theca cell lysates in this study show that $\mathrm{P}_{450 a r o m}$ with a molecular weight of $\sim 50 \mathrm{kDa}$ (Albrecht et al. 2001, Gen et al. 2001, Turner et al. 2002), was detected in granulosa cells, but not at all in theca cells (Fig. 6). Aromatase otherwise known as $\mathrm{P}_{450 \text { arom }}$ is an enzyme responsible for converting androgens to oestrogens in granulosa cells (Hillier et al. 1994, Johnson \& Everitt 1995, Brodie et al. 1999). Aromatase is a microsomal member of the cytochrome $\mathrm{P}_{450}$ superfamily, namely aromatase cytochrome $\mathrm{P}_{450}$, the product of the CYP19A1 (CYP19) gene (Simpson et al. 2002). Studies by Manikkam et al. (2001) and Garverick et al. (2002) reported that the expression of $m R N A$ for $\mathrm{P}_{450 \text { arom }}$ in the follicle was localized to granulosa cells. We have shown that aromatase levels were significantly increased in large follicles compared with small and medium follicles. More importantly and for the first time, to our knowledge, the results show that the level of aromatase was significantly decreased in large follicles in the follicular phase of lupin-fed ewes compared with control ewes. This suggests that lupin feeding may affect aromatase activity by decreasing its level in granulosa cells during the follicular phase of the oestrous cycle.
A

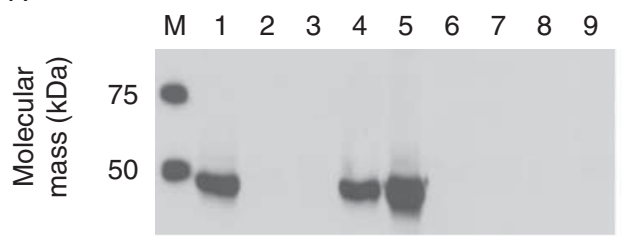

C

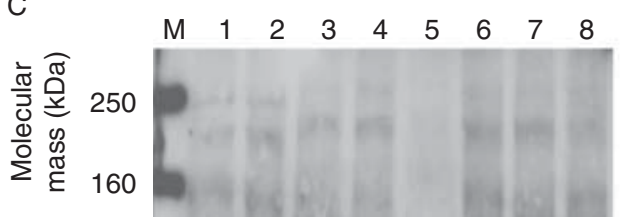

B

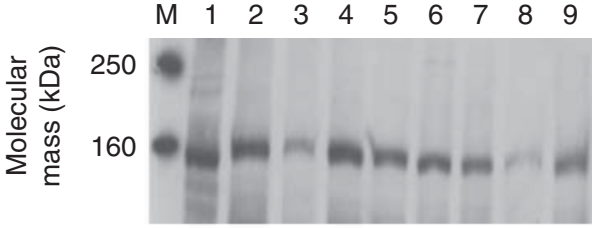

D

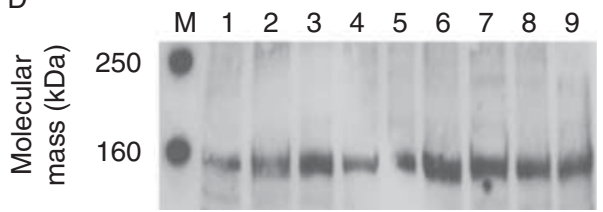

Figure 6 The example of immunoblotting of $\mathrm{P}_{450 a r o m}(\mathrm{~A})$, IRS-1 (B), IRS-2 (C) and IRS-4 (D). Lane M, molecular weight marker (kDa); lanes

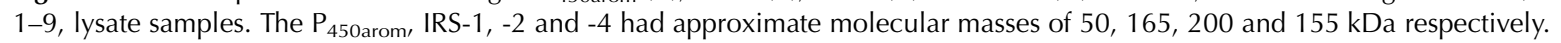


In addition, the level of aromatase in granulosa cells was positively correlated with the concentration of $E_{2}$ in follicular fluid.

We determined the level of IRS-1, -2 and -4 in theca and granulosa cells, but we did not measure IRS-3 because recent research attempting to clone the IRS-3 gene revealed the absence of a functional IRS-3 gene in humans and none of the molecular approaches have provided evidence for a functional IRS-3 gene in human tissue (Giovannone et al. 2000, Björnholm et al. 2002, Kokk et al. 2005). Furthermore, the absence of IRS-3 does not appear to influence fertility (Liu et al. 1999) and mice lacking IRS-3 have normal growth patterns and glucose homoeostasis (Liu et al. 1999).

There is little published information about the IRS proteins in ovarian tissue from normal animals, IRS- 1 is expressed in the luteinized rat ovary (Talavera et al. 1996), in follicular cells from the human (Wu et al. 2000, Dunaif et al. 2001) and in ovaries from the female rat (Richards 1994, Richards et al. 1995) while IRS-2 expression has been reported in theca and granulosa cells from female mice (Neganova et al. 2007) and studies using gene knockout mice suggest that IRS-2 and -4 are likely to be involved in mediating follicular responses to insulin (Fantin et al. 2000). At present, there are no published reports of IRSs in the sheep follicle, and our data report for the first time the presence of IRS-1, -2 and -4 in theca and granulosa cell lysates from sheep.

The IRSs are important components of insulin signalling pathways. This study shows that both theca and granulosa cells contain IRS-1, -2 and -4 at approximate molecular weights of 165,200 and $155 \mathrm{kDa}$ respectively (Sun et al. 1992, Fantin et al. 1998, Ross et al. 1998, Wu et al. 2000, Tsuruzoe et al. 2001). IRS-1 studies in human (Wu et al. 2000) and in mouse (Neganova et al. 2007) found that the level of IRS1 in theca and granulosa cells increased with follicular development but our own data do not agree with this finding. Studies from knockout mice suggest that IRS-1 mainly mediates mitogenic pathways of insulin signalling (Tamemoto et al. 1994, Withers et al. 1998) and increased levels of phosphorylated IRS-1 amplify insulinstimulated granulosa cell proliferation (Yen et al. 2004). Our study used follicles of $2 \mathrm{~mm}$ diameter and greater; in ewes, follicles of this size are not highly proliferative (Scaramuzzi et al. 2011). Our results show that IRS-1 was present at both stages of the oestrous cycle. We also found that the level of IRS- 1 in theca cells from large follicles was higher in the lupin-fed ewes during follicular phase. Concerning IRS-2, lupins increased its level in theca cells during the follicular phase and in granulosa cells during both the luteal and the follicular phases. This study provides some evidence to suggest that both IRS-1 and -2 are nutritionally regulated in sheep and that they are implicated in the nutritional regulation of folliculogenesis.
In this study, the general patterns of expression of IRS-1 and -2 in theca and granulosa cells were higher in response to nutrition in both luteal and follicular phases whereas IRS-4 in the theca was higher during the luteal phase but lower in the follicular phase. This pattern of expression of IRS-1, -2 and -4 in ovine follicles therefore supports our hypothesis that the insulin-glucose system is associated with nutritionally stimulated folliculogenesis. However, additional research is needed to precisely define the roles of the IRSs in modulating gonadotrophin-stimulated folliculogenesis.

These results show at least in the ewe that nutrition can directly alter the physiological function of ovarian follicles without any change in the circulating concentration of FSH. There was a significant increase in the number of follicles in the lupin-fed ewes, as well as increased granulosal and thecal IRSs and decreased levels of aromatase and these changes were associated with an increased number of follicles and lower concentrations of $E_{2}$ in follicular fluid and in peripheral blood.

In summary, a short-term supplement with lupin grain increased the number of follicles with no detectable change in live weight. However, there were increased plasma concentrations of insulin and glucose and decreased concentrations of $E_{2}$ in blood and follicular fluid; there were no effects on either FSH or progesterone. Thus, the gonadal responses to short-term nutritional supplementation appear to be associated with metabolic or nutritional signals to the follicle and specifically insulin rather than with weight. The IRSs are intracellular intermediates of insulin signalling and our data show that their levels are nutritionally regulated in the follicle suggesting a functional role in the nutritional stimulation of folliculogenesis in sheep. Beyond this, further interpretation is speculation, but it is tempting to suggest that the intra-follicular actions of insulin in the follicle may involve crosstalk with FSHstimulated aromatase (Scaramuzzi et al. 2010).

\section{Materials and Methods}

\section{Animals}

Forty-eight clinically healthy, Welsh Mountain ewes 2-3 years old were obtained from approved commercial sources. The animals were acclimatized for a week before the onset of the experiment. They were kept on straw bedding in group pens, fed with 500 g/ewe per day of a commercial concentrate diet (Ewe Feed, BOCM PAULS Ltd., Ipswich, Suffolk, UK; $18 \%$ protein; Metabolizable energy $(\mathrm{ME})=15.7 \mathrm{Mj} / \mathrm{kg}$ dry matter (DM) and given free access to good quality meadow hay $(10.8 \%$ crude protein and $\mathrm{ME}=8.3 \mathrm{MJ} / \mathrm{kg} \mathrm{DM})$; water was available ad libitum. The ewes were divided into four equal treatment groups: control-luteal phase ( $\mathrm{C}-\mathrm{L}$ group), lupin-fedluteal phase ( $\mathrm{L}-\mathrm{L}$ group), control-follicular phase (C-F group) and lupin-fed-follicular phase ( $\mathrm{L}-\mathrm{F}$ group). The experiment was carried out in October, during the breeding season. Animals in the lupin-fed groups were moved into individual 
pens $(1.5 \times 2.5 \mathrm{~m})$ a day before start of the lupinfeeding period. Oestrus was synchronized in all ewes with intra-vaginal progestagen sponges containing $30 \mathrm{mg}$ flugestone acetate (Chronogest, Intervet Ltd., Milton Keynes, Buckinghamshire, UK), for 12 days. During the period of sponge insertion, the ewes were trained to eat lupin grain (Lupinus luteus, variety Wodjil (spring sown), 40-44\% protein, $\mathrm{ME}=14.5 \mathrm{MJ} / \mathrm{kg} \mathrm{DM}$, and $6.5 \%$ oil, Innoseeds Ltd., Downham Market, Norfolk, UK). Ewes in the two lupin-fed groups were fed with a commercial concentrate diet until the day of sponge removal; they were then switched to a diet of meadow hay $(10.8 \%$ crude protein and $\mathrm{ME}=8.3 \mathrm{MJ} / \mathrm{kg} \mathrm{DM})$ and 8 days later the ewes in these groups were fed a supplement of 500 g/ewe per day of lupin grain for 5 days (days 6-11 of the oestrous cycle): $250 \mathrm{~g}$ in the morning (after blood collection at $0900 \mathrm{~h}$ ) and $250 \mathrm{~g}$ at $1700 \mathrm{~h}$. Animals in the two control groups were fed a commercial concentrate diet until sponge removal; then they were switched to a diet of meadow hay until the end of the experiment. Animals in the follicular phase groups received i.m. injections of $125 \mu \mathrm{g}$ of an analogue of $\mathrm{PGF}_{2 \alpha}$ (Estrumate, Schering-Plough Animal Health Ltd., Harefield, Middlesex, UK) on day 11 of the synchronized oestrous cycle (i.e. day 5 of the lupin-feeding period). The ewes were weighed at sponge removal, at the start of lupin feeding and at cull. All procedures involving live animals were conducted with the authorization of the Home Office and in compliance with the Animal (Scientific Procedures) Act, 1986.

\section{Blood collection}

Blood samples were taken at $0900 \mathrm{~h}$ every second day starting at the time of sponge removal until the start of the lupin-feeding period. At the start of lupin-feeding period, blood sampling regime was altered to twice daily at $0900 \mathrm{~h}$ (immediately before feeding) and $1400 \mathrm{~h}$ ( $5 \mathrm{~h}$ after feeding), this regime continued to the end of the lupin-feeding period. After PGF $2 \alpha$ injection, blood samples were taken at 14, 20 and $40 \mathrm{~h}$ after luteolysis induction in follicular phase group. All animals were culled at $40 \mathrm{~h}$ after $\mathrm{PGF}_{2 \alpha}$ injection. The blood was placed immediately in heparinized (200 IU) glass tubes. Plasma was separated by centrifugation at $4{ }^{\circ} \mathrm{C}$ and stored at $-20{ }^{\circ} \mathrm{C}$. Blood samples for glucose analysis were collected separately using $2.7 \mathrm{ml}$ glucose syringes (S-Monovette, containing $1.2 \mathrm{mg}$ EDTA $/ \mathrm{ml}$ blood and $1.0 \mathrm{mg}$ fluoride/ml blood, SARSTEDT, Aktiengesellschaft \& Co., Nümbrecht, Germany). The plasma was separated by centrifugation and stored as described earlier. The plasma containing heparin was analysed for insulin, FSH, $\mathrm{E}_{2}$ and progesterone and the plasma containing EDTA and fluoride was analysed for glucose.

\section{Collection and dissection of ovaries}

At the end of the experiment, the animals were killed with a captive bolt pistol followed by exsanguination. The ovaries were collected within 5 min of death and placed in ice-cold sterile saline. Both ovaries from nine ewes per group were dissected. The remaining ovaries were fixed in buffered formal saline. All visible follicles $>1.0 \mathrm{~mm}$ in diameter were dissected free from the ovarian stroma, using fine scissors and fine-toothed dissecting forceps, and placed in PBS in a sterile plastic Petri dish. Follicle diameter was measured to the nearest millimeter, using a graph paper grid placed under the dish. Each follicle was then hemisected in $1 \mathrm{ml}$ sterile PBS in a sterile plastic mini-Petri dish (NUNCLON, Nunc A/S Ltd., Roskilde, Denmark). The granulosa cell layer was gently scraped into the PBS using a sterile, fine plastic loop. The theca shell was placed in a sterile $1.5 \mathrm{ml}$ microtube (STAR Labs $\mathrm{GmbH}$, Ahrensburg, Germany). The PBS containing granulosa cells and follicular fluid was then placed in another $1.5 \mathrm{ml}$ microtube and centrifuged at $4{ }^{\circ} \mathrm{C}$ for $10 \mathrm{~min}$ at 13000 r.p.m. (approximately $18894 \mathrm{~g}$ ). Following centrifugation, the supernatant containing diluted follicular fluid was transferred into a $1.5 \mathrm{ml}$ microtube and stored at $-20{ }^{\circ} \mathrm{C}$. The separated theca shell and the granulosa cell pellet were stored at $-80{ }^{\circ} \mathrm{C}$. Follicular fluid was assayed for glucose, androstenedione, $\mathrm{E}_{2}$ and progesterone. Theca and granulosa cell lysates were prepared and the lysates were analysed for $\mathrm{P}_{450 \text { arom, }}$ IRS-1, -2 and -4 by western immunoblotting.

\section{Follicle classification}

Follicles were classified and processed according to their diameter as follows: i) follicles $>2.5 \mathrm{~mm}$ : individual follicles were separated into theca, granulosa and follicular fluid for individual analysis; ii) follicles $2.0-2.5 \mathrm{~mm}$ : follicles were pooled within ovaries (in batches of two to seven follicles), the pooled follicles were then separated into theca, granulosa and follicular fluid; and iii) follicles $<2.0 \mathrm{~mm}$ : all follicles were pooled within ovaries, the pooled follicles were then separated into theca, granulosa and follicular fluid. The theoretical volume of follicular fluid volume $(V)$ was calculated as described previously (Carson et al. 1981) using the formula: $V=0.52(D)^{2.7}$, where $V$ is the volume of fluid $\left(\mathrm{mm}^{3}\right)$ and $D$ is the follicle diameter $(\mathrm{mm})$.

For the analysis of follicle number, follicles were grouped into four classes based on their diameter: i) $<2.0 \mathrm{~mm}$, ii) $2.0-<2.5 \mathrm{~mm}$, iii) $2.5-\leq 3.5 \mathrm{~mm}$ and iv) $>3.5 \mathrm{~mm}$.

For the analysis of follicular fluid, follicles were grouped into two classes based on their diameter: i) $<3.5 \mathrm{~mm}$ and ii) $\geq 3.5 \mathrm{~mm}$; and oestrogenicity: i) non-oestrogenic $\left(E_{2}<100 \mathrm{ng} / \mathrm{ml}\right)$ and ii) oestrogenic follicles $\left(E_{2} \geq 100 \mathrm{ng} / \mathrm{ml}\right)$.

For the western blot analysis, granulosa and theca lysates from follicles $\geq 3.5 \mathrm{~mm}$ class were analysed individually, while follicles in the $2.0-<2.5$ and $2.5-\leq 3.5 \mathrm{~mm}$ classes were pooled within ovaries and analysed as a pool. This was necessary because there was insufficient protein from single follicles $<3.5 \mathrm{~mm}$ in diameter. Follicles in the $<2.0 \mathrm{~mm}$ class were not analysed.

\section{Glucose and hormone assays}

\section{Plasma analyses}

Glucose was analysed in $2 \mu$ l plasma, by colorimetry using the glucose oxidase phenol 4-aminoantipyrine peroxidase method (Randox test kits; Randox Laboratories Ltd., Crumlin Co., Antrim, UK) and an IMOLA automated analyzer (Randox Laboratories Ltd., Crumlin Co.). All samples were analysed in a single assay. The intra-assay coefficient of variation (CV) was 
$5.1 \%$. The limit of sensitivity for the glucose assay was $10.8 \mathrm{mg} / \mathrm{dl}$.

Insulin was analysed by RIA (Williams et al. 2001). The intraassay CV was $4.7 \%$. The inter-assay CV was $6.0 \%$ and the limit of sensitivity for the insulin assay was $0.05 \mathrm{ng} / \mathrm{ml}$.

FSH was analysed by RIA (Campbell et al. 1994). The intraassay CV was $11.3 \%$. The inter-assay CV was $8.8 \%$ and the limit of sensitivity for the FSH assay was $0.78 \mathrm{ng} / \mathrm{ml}$.

$\mathrm{E}_{2}$ was analysed by RIA (Mann \& Lamming 1995). The intraassay $\mathrm{CV}$ was $9.6 \%$. The inter-assay CV was $5.2 \%$ and the limit of sensitivity for the $E_{2}$ assay was $0.62 \mathrm{pg} / \mathrm{ml}$.

Progesterone was determined by RIA (Campbell et al. 1990). The intra-assay $\mathrm{CV}$ for low- $(0.5 \mathrm{ng} / \mathrm{ml})$, medium- $(1.0 \mathrm{ng} / \mathrm{ml})$ and high- $(4.0 \mathrm{ng} / \mathrm{ml})$ quality control plasmas were $17.8,10.8$ and $6.0 \%$ respectively. The inter-assay CV was $2.8 \%$ and the limit of sensitivity for the progesterone assay was $0.04 \mathrm{ng} / \mathrm{ml}$.

\section{Follicular fluid analyses}

Follicular fluid concentrations were corrected for dilution in $1 \mathrm{ml}$ PBS and are reported as concentrations of undiluted follicular fluid. Glucose was determined in individual follicles $\geq 2.5 \mathrm{~mm}$ in diameter, by colorimetry using the GOD/PAP method as described earlier but with $35 \mu$ of diluted follicular fluid. All the samples were analysed in a single assay. The intraassay $\mathrm{CV}$ was $3.6 \%$. The limit of sensitivity for the glucose assay was $0.018 \mathrm{mg} / \mathrm{dl}$.

Androstenedione was analysed by RIA (Campbell et al. 1998). The intra-assay CV for low- $(50 \mathrm{ng} / \mathrm{ml})$, medium$(250 \mathrm{ng} / \mathrm{ml})$, high-1 - $(400 \mathrm{ng} / \mathrm{ml})$ and high-2- $(800 \mathrm{ng} / \mathrm{ml})$ quality controls were $11.2,10.0,6.4$ and $16.8 \%$ respectively. The inter-assay CV was $9.2 \%$ and the limit of sensitivity for the androstenedione assay was $4.4 \mathrm{ng} / \mathrm{l}$.

$\mathrm{E}_{2}$ was analysed by RIA (Campbell et al. 1996). The intraassay CV for low- $(50 \mathrm{ng} / \mathrm{ml})$, medium- (250 ng/ml), high-1$(400 \mathrm{ng} / \mathrm{ml})$ and high-2- $(800 \mathrm{ng} / \mathrm{ml})$ quality controls were 9.0 , $19.1,4.9$ and $5.6 \%$ respectively. The inter-assay CV was $12.5 \%$ and the limit of sensitivity for the $E_{2}$ assay was $0.04 \mathrm{ng} / \mathrm{ml}$.

Progesterone was analysed by RIA (Campbell et al. 1998). The intra-assay CV for low- $(50 \mathrm{ng} / \mathrm{ml})$, medium- $(250 \mathrm{ng} / \mathrm{ml})$, high-1- $(400 \mathrm{ng} / \mathrm{ml})$ and high-2- $(800 \mathrm{ng} / \mathrm{ml})$ quality controls were $15.7,8.5,11.8$ and $3.1 \%$ respectively. The inter-assay CV was $13.9 \%$ and the limit of sensitivity for the progesterone assay was $3.9 \mathrm{ng} / \mathrm{ml}$.

\section{Western blot analysis}

Theca and granulosa cell lysates were analysed for $\mathrm{P}_{450 \text { arom, }}$ IRS-1, -2 and -4 by western immunoblotting (Somchit 2008). Briefly, SDS-PAGE was used to separate the proteins in the theca and granulosa cell lysates. Electrophoresis was carried out at $150 \mathrm{~V}$ and $400 \mathrm{~mA}$ for 75-100 min. Following electrophoresis, the gel was transferred to a PVDF membrane (Immobilon-P Transfer membranes, pore size $0.45 \mu \mathrm{m}$, Millipore Corporation, Billerica, MA, USA) and incubated in a blocker solution $(10 \%$ BSA or $10 \%$ skimmed milk). The PVDF membrane was then probed with a primary antibody against mouse anti-human cytochrome $\mathrm{P}_{450 \text { arom }}$ (Serotec Ltd., Kidlington, Oxfordshire, UK), rabbit polyclonal anti-IRS-1 (C-20, sc-559, Santa Cruz Biotechnology, Inc.), rabbit polyclonal anti-IRS-2 (H-205, sc-8299, Santa Cruz Biotechnology, Inc.), rabbit polyclonal anti-IRS-4 (Upstate Biotechnology, Inc., Lake Placid, NY, USA) or mouse monoclonal $\beta$-actin (AC-15, ab6276, abcam, Abcam plc, Cambridge Science Park, Cambridgeshire, UK) at working dilutions of 1:500, 1:250, 1:500, 1:1000 and 1:4000 respectively. After overnight incubation, the PVDF membrane was washed with TBST for $3 \times 20 \mathrm{~min}$. Horseradish peroxidase (HRP)-conjugated goat anti-mouse immunoglobulin specific polyclonal antibody (BD Biosciences Pharmingen, Oxford Science Park, Oxfordshire, UK) or ImmunoPure goat anti-rabbit IgG peroxidase conjugated (Pierce Biotechnology, Inc., Cramlington, Northumberland, UK) were used as the secondary antibodies at a working dilution of between 1:1000 and 1:10 000. The membrane was then washed in TBST, developed using an ECL detection method (ECL western blotting detection reagents, Amersham Biosciences) and exposed to film (Hyperfilm ECL high performance chemiluminescence film, Amersham Biosciences) for 5-10 min. The optical density of

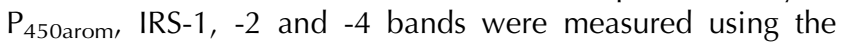
Quantity One Software Program version 4.4.0 (Bio-Rad Laboratories). The specific density of the $\mathrm{P}_{450 \text { arom, IRS-1, }-2}$ and -4 for each sample was calculated by subtraction of the background density and divided by the specific density of corresponding $\beta$-actin band or quality control band.

\section{Statistical analysis}

The statistical analyses were performed using the SPSS Statistical Software programme version 15.0 (SPSS, Inc.). All data are presented as the means \pm S.E.M. Where data were not normally distributed, they were transformed to logarithms. Data for hormone concentrations in plasma and body weight were analysed using a repeated measures, mixed model ANOVA with time as the within subject (within sheep) repeated measure and treatments (diet and stage of the oestrous cycle) as between subject (between sheep) factors. Data on hormone concentrations in follicular fluid and the

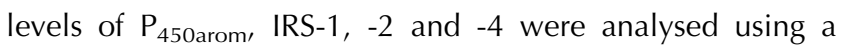
repeated measures, mixed model ANOVA with follicles within sheep as the within subject factor and treatments (diet and stage of the oestrous cycle) as between subject (between sheep) factors. For both methods, interactions were explored using 95\% Cls. Follicle numbers and distributions were tested by the $\chi^{2}$ test and correlation (either Pearson's or Spearman's) was used to examine the relationships among constituents of follicular fluid.

\section{Declaration of interest}

The authors declare that there is no conflict of interest that could be perceived as prejudicing the impartiality of the research reported.

\section{Funding}

The research was supported by a grant from the BBSRC (BB/0018420/1). 


\section{Acknowledgements}

The authors wish to thank Ms Catherine Pincott-Allen for technical assistance with the oestradiol-17 $\beta$ assays and Ms Sukanya Leethongdee, Mr Waliul Chowdhury, Mr Suppawiwat Ponglowhapan and Mr Pornchalit Assavacheep for assistance with the animal experiments.

\section{References}

Adams NR, Abordi JA, Briegel JR \& Sanders MR 1994 Effect of diet on the clearance of oestradiol-17 $\beta$ in the ewe. Biology of Reproduction 51 668-674. (doi:10.1095/biolreprod51.4.668)

Albrecht BA, MacLeod JN \& Daels PF 2001 Expression of 3ß-hydroxysteroid dehydrogenase, cytochrome p450 17 $\alpha$-hydroxylase/17,20-lyase and cytochrome p450 aromatase enzymes in corpora lutea of dioestrous and early pregnant mares. Theriogenology 55 551-561. (doi:10.1016/ S0093-691X(01)00425-3)

Björnholm M, He AR, Attersand A, Lake S, Liu SC, Lienhard GE, Taylor S, Arner P \& Zierath JR 2002 Absence of functional insulin receptor substrate-3 (IRS-3) gene in humans. Diabetologia 45 1697-1702. (doi:10.1007/s00125-002-0945-z)

Brodie A, Lu Q \& Long B 1999 Aromatase and its inhibitors. Journal of Steroid Biochemistry and Molecular Biology 69 205-210. (doi:10.1016/ S0960-0760(99)00051-5)

Brüning JC, Gautam D, Burks DJ, Gillette J, Schubert M, Orban PC, Klein R, Krone W, Müller-Wieland D \& Kahn CR 2000 Role of brain insulin receptor in control of body weight and reproduction. Science $\mathbf{2 8 9}$ 2122-2125. (doi:10.1126/science.289.5487.2122)

Burks DJ, Font de Mora J, Schubert M, Withers DJ, Myers MG, Towery HH, Altamuro SL, Flint CL \& White MF 2000 IRS-2 pathways integrate female reproduction and energy homeostasis. Nature 407 377-382. (doi:10.1038/35030105)

Campbell BK, Mann GE, McNeilly AS \& Baird DT 1990 The pattern of ovarian inhibin, oestradiol and androstenedione secretion during the oestrous cycle in the ewe. Endocrinology 127 227-235. (doi:10.1210/ endo-127-1-227)

Campbell BK, Gordon BM \& Scaramuzzi RJ 1994 The effect of ovarian arterial infusion of transforming growth factor $\alpha$ on ovarian follicles populations and ovarian hormone secretion in ewes with an autotransplanted ovary. Journal of Endocrinology 143 13-24. (doi:10.1677/ joe.0.1430013)

Campbell BK, Scaramuzzi RJ \& Webb R 1996 Induction and maintenance of oestradiol and immunoreactive inhibin production with FSH by ovine granulosa cells cultured in serum-free media. Journal of Reproduction and Fertility 106 7-16. (doi:10.1530/jrf.0.1060007)

Campbell BK, Baird DT \& Webb R 1998 Effects of dose of LH on androgen production and luteinization of ovine theca cells cultured in a serum-free system. Journal of Reproduction and Fertility 112 69-77. (doi:10.1530/ jrf.0.1120069)

Carson RS, Findlay JK, Clarke IJ \& Burger HG 1981 Oestradiol, testosterone, and androstenedione in ovine follicular fluid during growth and atresia of ovarian follicles. Biology of Reproduction 24 105-113. (doi:10.1095/biolreprod24.1.105)

Chang SCS, Jones JD, Ellefson RD \& Ryan RJ 1976 The porcine ovarian follicle: I. Selected chemical analysis of follicular fluid at different developmental stages. Biology of Reproduction 15 321-328. (doi:10.1095/biolreprod15.3.321)

Downing JA \& Scaramuzzi RJ 1991 Nutrient effects on ovulation rate, ovarian function and the secretion of gonadotrophic and metabolic hormones in sheep. Journal of Reproduction and Fertility. Supplement 43 209-227.

Downing JA, Joss J \& Scaramuzzi RJ 1995a Ovulation rate and the concentrations of gonadotrophins and metabolic hormones in ewes infused with glucose during the late luteal phase of the oestrous cycle. Journal of Endocrinology 146 403-410. (doi:10.1677/joe.0.1460403)

Downing JA, Joss J, Connell P \& Scaramuzzi RJ 1995b Ovulation rate and the concentrations of gonadotrophic and metabolic hormones in ewes fed lupin grain. Journal of Reproduction and Fertility 103 137-145. (doi:10.1530/jrf.0.1030137)
Downing JA, Joss J \& Scaramuzzi RJ 1995 C A mixture of the branched chain amino acids leucine, isoleucine and valine increases ovulation rate in ewes when infused during the late luteal phase of the oestrous cycle: an effect that may be mediated by insulin. Journal of Endocrinology 145 315-323. (doi:10.1677/joe.0.1450315)

Downing JA, Joss J \& Scaramuzzi RJ 1999 The effect of a direct arterial infusion of insulin and glucose on the ovarian secretion rates of androstenedione and oestradiol in ewes with an autotransplanted ovary. Journal of Endocrinology 163 531-541. (doi:10.1677/joe.0. 1630531)

Dunaif A, Wu X, Lee A \& Diamanti-Kandarakis E 2001 Defects in insulin receptor signaling in vivo in the polycystic ovary syndrome (PCOS). American Journal of Physiology. Endocrinology and Metabolism 281 E392-E399.

Evans ACO \& Martin F 2000 Kinase pathways in dominant and subordinate ovarian follicles during the first wave of follicular development in sheep. Animal Reproduction Science 64 221-231. (doi:10.1016/S03784320(00)00210-4)

Fantin VR, Sparling JD, Slot JW, Keller SR, Lienhard GE \& Lavan BE 1998 Characterization of insulin receptor substrate 4 in human embryonic kidney 293 cells. Journal of Biological Chemistry 273 10726-10732. (doi:10.1074/jbc.273.17.10726)

Fantin VR, Wang Q, Lienhard GE \& Keller SR 2000 Mice lacking insulin receptor substrate 4 exhibit mild defects in growth, reproduction, and glucose homeostasis. American Journal of Physiology. Endocrinology and Metabolism 278 E127-E133.

Ferguson EM, Ashworth CJ, Edwards SA, Hawkins N, Hepburn N \& Hunter MG 2003 Effect of different nutritional regimens before ovulation on plasma concentrations of metabolic and reproductive hormones and oocyte maturation in gilts. Reproduction 126 61-71. (doi:10.1530/rep.0. 1260061)

Garverick HA, Baxter G, Gong J, Armstrong DG, Campbell BK, Gutierrez CG \& Webb R 2002 Regulation of expression of ovarian mRNA encoding steroidogenic enzymes and gonadotrophin receptors by FSH and GH in hypogonadotrophic cattle. Reproduction 123 651-661. (doi:10.1530/rep.0.1230651)

Gen K, Okuzawa K, Kumakura N, Yamaguchi S \& Kagawa H 2001 Correlation between messenger RNA expression of cytochrome p450 aromatase and its enzyme activity during oocyte development in the Red Sea bream (Pagrus major). Biology of Reproduction 65 1186-1194. (doi:10.1095/biolreprod65.4.1186)

Giovannone B, Scaldaferri ML, Federici M, Porzio O, Lauro D, Fusco A, Sbraccia P, Borboni P, Lauro R \& Sesti G 2000 Insulin receptor substrate (IRS) transduction system: distinct and overlapping signaling potential. Diabetes/Metabolism Research and Reviews 16 434-441. (doi:10.1002/ 1520-7560(2000)9999:9999 <::AID-DMRR159>3.0.CO;2-8)

Gong JG, Armstrong DG, Baxter G, Hogg CO, Garnsworthy PC \& Webb R 2002 The effect of increased dietary intake on superovulatory response to FSH in heifers. Theriogenology 57 1591-1602. (doi:10.1016/S0093691X(02)00668-4)

Gutiérrez CG, Oldham J, Bramley TA, Gong JG, Campbell BK \& Webb R 1997 The recruitment of ovarian follicles is enhanced by increased dietary intake in heifers. Journal of Animal Science 75 1876-1884.

Haresign W 1981 The influence of nutrition on reproduction in the ewe. 1. Effects on ovulation rate, follicle development and luteinizing hormone release. Animal Reproduction 32 197-202.

Henderson KM \& Franchimont P 1981 Regulation of inhibin production by bovine ovarian cells in vitro. Journal of Reproduction and Fertility $\mathbf{6 3}$ 431-442. (doi:10.1530/jrf.0.0630431)

Hillier SG, Whitelaw PF \& Smyth CD 1994 Follicular oestrogen synthesis: the 'two-cell, two-gonadotrophin' model revisited. Molecular and Cellular Endocrinology 100 51-54. (doi:10.1016/0303-7207(94) 90278-X)

Johnson MH \& Everitt BJ 1995 Ovarian function. In Essential Reproduction, 4th edn, pp 60-78. Eds MH Johnson\& BJ Everitt. UK: Blackwell Science Ltd.

Kokk K, Veräjänkorva E, Laato M, Wu XK, Tapfer H \& Pöllänen P 2005 Expression of insulin receptor substrates 1-3, glucose transporters GLUT-1-4, signal regulatory protein $1 \alpha$, phosphatidylinositol 3-kinase and protein kinase B at the protein level in the human testis. Anatomical Science Internationa/ 80 91-96. (doi:10.1111/j.1447-073x.2005.00091.x) 
King L Jr, Maciorowski K, Powell KM, Weidner S \& Eley CL 1991 Lupin as a protein supplement for growing lambs. Journal of Animal Science 69 3398-3405.

Landau S, Braw-Tal R, Kaim M, Bor A \& Bruckental I 2000 Preovulatory follicular status and diet affect the insulin and glucose content of follicles in high-yielding dairy cows. Animal Reproduction Science 64 181-197. (doi:10.1016/S0378-4320(00)00212-8)

Letelier C, Gonzalez-Bulnes A, Herve M, Correa J \& Pulido R 2008a Enhancement of ovulatory follicle development in maiden sheep by short-term supplementation with steam-flaked corn. Reproduction in Domestic Animals 43 222-227. (doi:10.1111/j.1439-0531.2007.00885.x)

Letelier C, Mallo F, Encinas T, Ros JM \& Gonzalez-Bulnes A $2008 b$ Glucogenic supply increases ovulation rate by modifying follicle recruitment and subsequent development of preovulatory follicles without effects on ghrelin secretion. Reproduction 136 1-8. (doi:10.1530/REP08-0010)

Letelier CA, Contreras-Solis I, Garcia-Fernandez RA, Ariznavarreta C, Tresguerres JAF, Flores JM \& Gonzalez-Bulnes A 2009 Ovarian follicular dynamics and plasma steroid concentrations are not significantly different in ewes given intravaginal sponges containing either 20 or $40 \mathrm{mg}$ of fluorogestone acetate. Theriogenology 71 676-682. (doi:10.1016/j.theriogenology.2008.09.030)

Lindsay DR 1976 The usefulness to the animal producer of research findings in nutrition on reproduction. Proceedings of the Australian Society of Animal Production 11 217-224.

Liu SCH, Wang Q, Lienhard GE \& Keller SR 1999 Insulin receptor substrate 3 is not essential for growth or glucose homeostasis. Journal of Biological Chemistry 274 18093-18099. (doi:10.1074/jbc.274.25.18093)

Manikkam M, Calder MD, Salfen BE, Youngquist RS, Keisler DH \& Garverick HA 2001 Concentrations of steroids and expression of messenger RNA for steroidogenic enzymes and gonadotropin receptors in bovine ovarian follicles of first and second waves and changes in second wave follicles after pulsatile LH infusion. Animal Reproduction Science 67 189-203. (doi:10.1016/S0378-4320(01)00120-8)

Mann GE \& Lamming GE 1995 Effect of the level of oestradiol on oxytocininduced prostaglandin F2 $\alpha$ release in the cow. Journal of Endocrinology 145 175-180. (doi:10.1677/joe.0.1450175)

Muñoz-Gutiérrez M, Blache D, Martin GB \& Scaramuzzi RJ 2002 Folliculogenesis and ovarian expression of mRNA encoding aromatase in anoestrous sheep after 5 days of glucose or glucosamine infusion or supplementary lupin feeding. Reproduction 124 721-731. (doi:10.1530/ rep.0.1240721)

Muñoz-Gutiérrez M, Findlay PA, Adam CL, Wax G, Campbell BK, Kendall NR, Khalid M, Forsberg M \& Scaramuzzi RJ 2005 The ovarian expression of mRNAs for aromatase, IGF-I receptor, IGF-binding protein$2,-4$ and -5 , leptin and leptin receptor in cycling ewes after three days of leptin infusion. Reproduction 130 869-881. (doi:10.1530/rep.1.00557)

Neganova I, Al-Qassab H, Heffron H, Selman C, Choudhury AI, Lingard SJ, Diakonov I, Patterson M, Ghatei M, Bloom SR et al. 2007 Role of central nervous system and ovarian insulin receptor substrate 2 signaling in female reproductive function in the mouse. Biology of Reproduction $\mathbf{7 6}$ 1045-1053. (doi:10.1095/biolreprod.106.059360)

Nottle MB, Armstrong DT, Setchell BP \& Seamark RF 1985 Lupin feeding and folliculogenesis in the Merino ewe. Proceedings of the Nutrition Society of Australia 10145.

Oldham CM \& Lindsay DR 1984 The minimum period of intake of lupin grain required by ewes to increase their ovulation rate when grazing dry summer pasture. In Reproduction in Sheep, pp 274-276. Eds DR Lindsay \& DT Pearce. Cambridge: Cambridge University Press.

Pearse BHG, McMeniman NP \& Gardner IA 1994 Influence of body condition on ovulatory response to lupin (Lupinus angustifolius) supplementation of sheep. Small Ruminant Research 13 27-32. (doi:10.1016/0921-4488(94)90027-2)

Peluso J, Delidow BC, Lynch J \& White BA 1991 Follicle-stimulating hormone and insulin regulation of $17 \beta$-oestradiol secretion and granulosa cell proliferation within immature rat ovaries maintained in perifusion culture. Endocrinology 128 191-196. (doi:10.1210/endo128-1-191)

Richards JS 1994 Hormonal control of gene expression in the ovary. Endocrine Reviews 15 725-751.

Richards MW, Spicer LJ \& Wettemann RP 1995 Influence of diet and ambient temperature on bovine serum insulin-like growth factor-I and thyroxine: relationships with non-esterified fatty acids, glucose, insulin, luteinizing hormone and progesterone. Animal Reproduction Science 37 267-279. (doi:10.1016/0378-4320(94)01338-M)

Ross SA, Lienhard GE \& Lavan BE 1998 Association of insulin receptor substrate 3 with $\mathrm{SH} 2$ domain-containing proteins in rat adipocytes. Biochemical and Biophysical Research Communications 247 487-492. (doi:10.1006/bbrc.1998.8821)

Rubio JM, Hallford DM \& Hawkins DE 1997 Effect of glucose administration during the oestrous cycle on serum hormone profiles, mRNA for steroidogenic enzymes, and breeding performance of ewes. Journal of Animal Science 75 775-780.

Scaramuzzi RJ, Campbell BK, Downing JA, Kendall NR, Khalid M, Muñoz-Gutiérrez M \& Somchit A 2006 A review of the effects of supplementary nutrition in the ewe on the concentrations of reproductive and metabolic hormones and the mechanisms that regulate folliculogenesis and ovulation rate. Reproduction, Nutrition, Development 46 339-354. (doi:10.1051/rnd:2006016)

Scaramuzzi RJ, Brown HM \& Dupont J 2010 Nutritional and metabolic mechanisms in the ovary and their role in mediating the effects of diet on folliculogenesis: a perspective. Reproduction in Domestic Animals 45 (Suppl 3) 32-41. (doi:10.1111/j.1439-0531.2010.01662.x)

Scaramuzzi RJ, Baird DT, Campbell BK, Driancourt MA, Dupont J, Fortune JE, Gilchrist RB, Martin GB, McNatty KP, McNeilly AS et al. 2011 Regulation of folliculogenesis and the determination of ovulation rate in ruminants. Reproduction, Fertility, and Development 23 444-467. (doi:10.1071/RD09161)

Simpson ER, Clyne C, Rubin G, Boon WC, Robertson K, Britt K, Speed C \& Jones M 2002 Aromatase - a brief overview. Annual Review of Physiology 64 93-127. (doi:10.1146/annurev.physiol.64.081601.142703)

Somchit A 2008 The physiological regulation of folliculogenesis by the insulin-glucose system and by the perturbation of the follicular negative feedback system. PhD Thesis, p 264. University of London, UK.

Somchit A, Campbell BK, Khalid M, Kendall NR \& Scaramuzzi RJ 2007 The effect of short-term nutritional supplementation of ewes with lupin grain (Lupinus luteus), during the luteal phase of the oestrous cycle on the number of ovarian follicles and the concentrations of hormones and glucose in plasma and follicular fluid. Theriogenology 68 1037-1046. (doi:10.1016/j.theriogenology.2007.08.001)

Sun XJ, Miralpeix M, Myers MG Jr, Glasheen EM, Backer JM, Kahn CR \& White MF 1992 Expression and function of IRS-1 in insulin signal transmission. Journal of Biological Chemistry $26722662-22672$.

Talavera F, Chen Z \& Menon KM 1996 IRS-I expression on the luteinized rat ovary: IGF-I and cyclic AMP effects on IRS-I tyrosine phosphorylation. Biochimica et Biophysica Acta 1310 10-18. (doi:10.1016/01674889(95)00129-8)

Tamemoto H, Kadowaki T, Tobe K, Yagi T, Sakura H, Hayakawa T, Terauchi Y, Ueki K, Kaburagi Y \& Satoh S 1994 Insulin resistance and growth retardation in mice lacking insulin receptor substrate-1. Nature 372 182-186. (doi:10.1038/372182a0)

Teleni E, Rowe JB, Croker KP, Murray PJ \& King WR 1989 Lupins and energy-yielding nutrients in ewes. II. Response in ovulation rate in ewes to increased availability of glucose, acetate and amino acids. Reproduction, Fertility, and Development 1 117-125. (doi:10.1071/ RD9890117)

Tsuruzoe K, Emkey R, Kriauciunas KM, Ueki K \& Khan CR 2001 Insulin receptor substrate 3 (IRS-3) and IRS-4 impair IRS-1 and IRS-2-mediated signalling. Molecular and Cellular Biology 21 26-38. (doi:10.1128/ MCB.21.1.26-38.2001)

Turner KJ, Macpherson S, Millar MR, McNeilly AS, Williams K, Cranfield M, Groome NP, Sharpe RM, Fraser HM \& Saunders PTK 2002 Development and validation of a new monoclonal antibody to mammalian aromatase. Journal of Endocrinology 172 21-30. (doi:10. 1677/joe.0.1720021)

Viñoles C, Forsberg M, Martin GB, Cajarville C, Repetto J \& Meikle A 2005 Short-term nutritional supplementation of ewes in low body condition affects follicle development due to an increase in glucose and metabolic hormones. Reproduction 129 299-309. (doi:10.1530/rep.1.00536)

Williams SA, Blache D, Martin GB, Foot R, Blackberry MA \& Scaramuzzi RJ 2001 Effect of nutritional supplementation on quantities of glucose transporters 1 and 4 in sheep granulosa and theca cell. Reproduction 122 947-956. (doi:10.1530/rep.0.1220947) 
Wise T 1987 Biochemical analysis of bovine follicular fluid: albumin, total protein, lysosomal enzymes, ions, steroids and ascorbic acid content in relation to follicular size, rank, atresia classification and day of oestrous cycle. Journal of Animal Science 64 1153-1169.

Withers DJ, Gutierrez JS, Towery H, Burks DJ, Ren JM, Previs S, Zhang Y, Bernal D, Pons S, Shulman GI et al. 1998 Disruption of IRS-2 causes type 2 diabetes in mice. Nature 391 900-904. (doi:10.1038/36116)

Wu XK, Sallinen K, Anttila L, Mäkinen M, Luo C, Pöllänen P \& Erkkola R 2000 Expression of insulin-receptor substrate-1 and -2 in ovaries from women with insulin resistance and from controls. Fertility and Sterility $\mathbf{7 4}$ 564-572. (doi:10.1016/S0015-0282(00)00688-9)
Yen HW, Jakimiuk AJ, Munir I \& Magoffin DA 2004 Selective alterations in insulin receptor substrates-1, -2 and -4 in theca but not granulosa cells from polycystic ovaries. Molecular Human Reproduction 10 473-479. (doi:10.1093/molehr/gah066)

Received 12 April 2012

First decision 15 June 2012

Revised manuscript received 15 November 2012

Accepted 21 January 2013 